\title{
Assessment of swim-up and discontinuous density gradient in sperm sex preselection for bovine embryo production
}

\author{
[Avaliação do swim-up e do gradiente descontinuo de densidade na pré-seleção do sexo \\ de espermatozoides na produção de embriões bovinos]

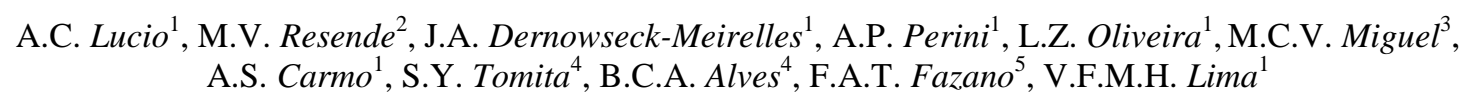 \\ ${ }^{1}$ Universidade "Julio de Mequita Filho" - Faculdades de Ciências Agrárias e Veterinárias - Jaboticabal, SP \\ ${ }^{2}$ Universidade Federal da Bahia - Salvador - Ba \\ ${ }^{3}$ Universidade "Julio de Mequita Filho" - Faculdade de Medicina Veterinária de Araçatuba - Araçatuba, SP \\ ${ }^{4}$ Prime-Embryo - Biotecnologia da Reprodução Animal - Botucatu, SP \\ ${ }^{5}$ UNICAMP - Campinas - SP
}

\begin{abstract}
The purpose of this work was to associate the modified swim-up method with centrifugation in density gradient for the separation of X-bearing spermatozoa. Sperm viability and integrity were evaluated through the Trypan Blue/Giemsa staining method. Quality control of centrifuged spermatozoa was performed in in vitro produced embryos. The results were validated by the sex ratio of in vitro produced embryos using PCR by $\mathrm{Y}$ - specific sequences present in bovine male genomic DNA. After determining genetic sex of in vitro produced embryos, the results showed difference $(\mathrm{P}<0.05)$ in deviation of sex ratio when comparing the control group ( $45.2 \%$ females) with the other spermatozoa selection procedures $(60.6 \%$ females $)(\mathrm{P}<0.05)$. The sperm selection methods are capable of selecting $\mathrm{X}$-bearing spermatozoa without compromising the spermatozoa fertility (cleavage and blastocyst rates, $70 \%$ and $26 \%$, respectively) and were considered relevant methods to be introduced in bovine in vitro produced embryo programs.
\end{abstract}

Keywords: density gradient centrifugation, embryo sex ratio, Percoll ${ }^{\mathrm{TM}}$, swim-up

\section{RESUMO}

$O$ objetivo do presente trabalho foi associar o método de swim-up modificado à centrifugação em gradiente de densidade para a separação de espermatozoides portadores do cromossomo X. A viabilidade e a integridade espermática foram avaliadas pelo método de coloração Azul de Tripan e Giemsa. $O$ controle de qualidade dos espermatozoides centrifugados foi realizado por meio da produção in vitro de embriões bovinos. Os resultados foram validados pela técnica de PCR para verificar a proporção sexual dos embriões produzidos in vitro, com o uso de sequências $Y$ especificas presente no DNA genômico de machos bovinos. Após determinar o sexo genético dos embriões produzidos in vitro, os resultados não mostraram diferença $(P<0,05)$ no desvio da proporção do sexo quando comparou o grupo controle (45,2\% de fêmeas) com os outros processos de seleção de espermatozoides $(60,6 \%$ de fêmeas) $(P<0,05)$. Os métodos de seleção de espermatozoides são capazes de selecionar espermatozoides portadores do cromossomo $X$ sem comprometer a fertilidade, medida pelas taxas de clivagem e blastocisto de $70 \%$ e 26\%, respectivamente, e foram considerados métodos de relevância para serem introduzidos nos programas de produção in vitro de embriões bovinos.

Palavras-chaves: bovino, centrifugação em gradiente de densidade, Percoll ${ }^{\mathrm{TM}}$, sexagem de embriões, swim-up

Recebido em 3 de outubro de 2011

Aceito em 12 de janeiro de 2012

E-mail alinelucio@hotmail.com 


\section{INTRODUCTION}

Methods for sorting bovine sperm into X- and Ybearing fractions could have a major impact on dairy cattle production, in particular an increase of the reproductive efficiency in breeding programs. Isolation of X-bearing sperm could have important consequences with respect to the availability and affordability of dam selection and heifer replacement (Weigel, 2004; De Vries, 2008), and increase the effectiveness of AI progeny testing programs, as well as the efficiency of multiple ovulation and embryo transfer (MOET) and in vitro embryo production (IVP) programs (Weigel, 2004). In fact, sex preselection of implantation embryos, combined with embryo transfer and genetic improvement programs, can increase the profitability of dairy cattle production (De Vries, 2008).

The commercially available technology for separating $\mathrm{X}$ - and Y-bearing spermatozoa is flow cytometry with $90 \%$ accuracy (Johnson, 2000) and the use of sexed semen technology is the apparent lower fertility of sorted sperm (Palma et al., 2008). The sorting procedure might be responsible for variations in cleavage (0 to $89 \%$ ) and blastocyst rates (3.5 to 28.8\%) (Palma et al., 2008; Borchersen and Peacock, 2009). There are clear altered mRNA expression patterns of developmentally important genes in in vitro produced embryos using sorted semen, showing that sperm sexing by flow cytometry may result in sperm damage, semen fertility reduction (Morton et al., 2007) and ongoing pregnancy failure (Perez-Crespo et al., 2008). Therefore, other sperm sex selection methods with the purpose of preserving sperm viability have been developed such as the swim-up (Madrid-Burry et al., 2003) method and Percoll ${ }^{\mathrm{TM}}$ density gradient centrifugation (Hossepian de Lima, 2007).

Percoll ${ }^{\mathrm{TM}}$ density gradient centrifugation has been used in humans and cattle to separate sperm cells carrying an $\mathrm{X}$ or $\mathrm{Y}$ chromosome (Hossepian de Lima, 2007). Selection by Percoll ${ }^{\mathrm{TM}}$ discontinuous gradient enhances sperm motility (Parrish et al., 1995; Lucio et al., 2008), percentage of cells with normal morphology (Prakash et al., 1998), intact membrane and intact acrosome (Oliveira et al., 2011). Centrifugation of semen in natura in density gradient was capable of separating about $70 \%$ of $\mathrm{X}$-bearing viable sperm (Hossepian de Lima,
2007) with lower cost and without damages to the sperm acrosome (Resende et al., 2010) and plasmatic membrane (Oliveira et al., 2011). The swim-up method is based on the difference of swimming speed between $\mathrm{X}$ - and Y-bearing spermatozoon (Rodriguez-Martinez et al., 1997) and can be used for sperm sex pre-selection (Cesari et al., 2006; Yan et al., 2006).

The purpose of this work was to evaluate sex ratio deviation of in vitro produced embryos using thawed semen in density gradient centrifugation, modified swim-up and modified swim-up associated to density gradient centrifugation

\section{MATERIALS AND METHODS}

All reagents used in this study were obtained from Sigma-Aldrich (St Louis, MO, USA). Percoll $^{\mathrm{TM}}$ was obtained from Pharmacia Fine Chemicals (Uppsala, Sweden), and BSA was obtained from Calbiochem (Darmstadt, Germany).

Cryopreserved bovine semen was obtained from two Gir Brazilian (Bos indicus) and two Jersey bulls (Bos taurus), from a commercial company. All sperm samples were evaluated, before and after the treatments, for concentration, total motility and vigor. The percentages of total motile sperm and vigor were determined subjectively, on a drop of semen placed in a prewarmed glass-slide covered with a coverslip, and examined under a bright-field microscope at 400X magnification. Sperm concentration was determined in a hemocytometer in a 1:200 dilution.

Percoll $^{\mathrm{TM}}$ discontinuous gradient was prepared by mixing DMEM isotonic solutions $(\mathrm{pH} 7.4$, 280 to $\left.290 \mathrm{mOsm} / \mathrm{kg} / \mathrm{H}_{2} 0\right)$ with Percoll ${ }^{\mathrm{TM}}$ stock solution with $0.3 \%$ (wt/vol) BSA, for different densities obtained ranging from 1.110 to $1.123 \mathrm{~g} / \mathrm{mL}$ (Hossepian de Lima, et al., 2004). The three layers of discontinuous density gradient were disposed from the larger density (bottom of the tube) to the minor into $15 \mathrm{~mL}$ conical centrifuge tubes.

For centrifugation, about 40 million frozenthawed sperm were overlaid on Percoll ${ }^{\mathrm{TM}}$ discontinuous density gradient. The gradients were centrifuged at $500 \mathrm{x} \mathrm{g}$ for 15 minutes, at 
$22^{\circ} \mathrm{C}$. After centrifugation, the supernatants were removed, the pellets were recovered and sperm motility evaluated. The centrifuged and recovered sperm were used for in vitro fertilization, with a final concentration of $100 \mathrm{x}$ $10^{3}$ spermatozoa/ 20 oocytes.

The modified swim-up was performed according Irianni and Coddington (1992).

The thawed semen samples were deposited in $15 \mathrm{~mL}$ conical centrifuge tubes containing $5.0 \mathrm{~mL}$ of DMEM and centrifuged twice at $300 \mathrm{x}$ g for 5 minutes for extender removal. After the second centrifugation the supernatant was discarded and $1.0 \mathrm{~mL}$ of DMEM medium supplemented with $0.3 \%$ BSA was deposited over the pellet, with addition of HEPES. The tube was maintained in an incubator at $38.5^{\circ} \mathrm{C}$ for $1 \mathrm{~h}$. After this period, $1.0 \mathrm{~mL}$ of supernatant with approximately $20 \times 10^{6}$ spermatozoa was recovered and sperm motility and vigor were evaluated. The centrifuged and recovered sperm were used for in vitro fertilization, with a final concentration of $100 \times 10^{3}$ spermatozoa/20 oocytes.

About 80 million frozen-thawed sperm were submitted to the modified swim-up. The supernatant was recovered and overlaid on Percoll ${ }^{\mathrm{TM}}$ discontinuous density gradient. The gradients were centrifuged and the sperm pellets were recovered. Sperm motility and vigor were evaluated and the recovered and centrifuged sperm were used for in vitro fertilization, with a final concentration of $100 \times 10^{3}$ spermatozoa/20 oocytes.

Sperm membrane and acrossome integrity were assessed using the vital stain Tripan Blue/Giemsa (Sigma-Aldrich St Louis, MO, USA), as described by Kovacs and Foote (1992). An aliquot of semen $(20 \mu \mathrm{L})$ was added to the stain solution $(20 \mu \mathrm{L}$ Tripan Blue $0,4 \%)$ and incubated at $37^{\circ} \mathrm{C}$ for 20 minutes. Semen with the stain solution was washed twice in $1 \mathrm{~mL}$ of distillated water at $700 \mathrm{x} g$ for 5 minutes. The supernatant was discarded and the pellet was resuspended in $0.5 \mathrm{~mL}$ of distillated water and an aliquot of $10 \mu \mathrm{L}$ was placed on 2 slides and two smears were made from each sample, fixed with methanol for 5 minutes, dried and stained for 18 to 20 hours with Giemsa (10\%). For all samples, 100 cells were examined in each slide at $1000 \mathrm{X}$ magnification. The sperm was classified as: live with non-reacted acrosome (LWI), live reacted acrosome (LWA), dead with non-reacted acrosome (DWI) and dead reacted acrosome (DWA).

Bovine ovaries were collected at the slaughterhouse and transported to the laboratory in saline solution at $33^{\circ} \mathrm{C}$. Immature cumulus oocyte complexes (COCs) from follicles between 2 and $8 \mathrm{~mm}$ diameter were aspirated. The COCs were washed in TCM-199 (GIBCO BRL; Grand Island, USA), supplemented with $0.2 \mathrm{mM}$ of sodium pyruvate, $20 \mathrm{mM}$ of HEPES, $5 \mathrm{mM}$ of sodium bicarbonate, $16.67 \mu \mathrm{g} / \mathrm{mL}$ of gentamicin (Sigma-Aldrich St Louis, MO, USA). The oocytes were matured in TCM-199 supplemented with $0.2 \mathrm{mM}$ of sodium pyruvate, $25 \mathrm{mM}$ of sodium bicarbonate, $16.67 \mu \mathrm{g} / \mathrm{mL}$ of gentamicin, $1 \mu \mathrm{g} / \mathrm{mL}$ of $17-\beta$ estradiol, $0.5 \mu \mathrm{g} / \mathrm{mL}$ of FSH (Folltropin ${ }^{\mathrm{TM}}$, Bioniche Animal Health, Belleville, EUA), $100 \mathrm{UI} / \mathrm{mL}$ of hCG (Profasi $\mathrm{HP}^{\mathrm{TM}}$; Profasi ${ }^{\mathrm{TM}}$, Serono, Sao Paulo, Brazil), plus $10 \%$ fetal bovine serum. Twenty COCs per microdroplets were matured in humid atmosphere containing $5 \% \mathrm{CO}_{2}$, for 22 hours, at $38.5^{\circ} \mathrm{C}$.

For in vitro fertilization (IVF), the matured oocytes were distributed in four groups: control group, modified swim-up, density gradient and modified swim-up associated to density gradient. In the control group, the straws were thawed at $35^{\circ} \mathrm{C}$ for 30 seconds, and layered on top of a gradient composed of $1 \mathrm{~mL}$ fraction of $45 \%$ and $90 \%$ isotonic Percoll ${ }^{\mathrm{TM}}$. After centrifugation at $900 \mathrm{x} \mathrm{g}$ for 30 minutes, the supernatant was discarded, and the pellet was adjusted with fertilization medium to obtain a final concentration of $100 \times 10^{3}$ spermatozoa in each fertilization droplet. The oocytes and sperm were incubated for 20 hours in $5 \% \mathrm{CO}_{2}$, in humidified air at $38.5^{\circ} \mathrm{C}$, in TALP-IVF medium. Presumptive zygotes were denuded and cocultured with synthetic oviduct fluid (SOF) medium, and then transferred to 4 well dishes, and embryo culture was carried out at $38.5^{\circ} \mathrm{C}$ in a humid atmosphere containing $5 \% \mathrm{CO}_{2}, 5 \% \mathrm{O}_{2}$ and $90 \% \mathrm{~N}_{2}$ (Vajta et al., 1999). Cleavage was assessed 48 hours after IVF and blastocyst stage on day 7 to 8 of culture. Fetal calf serum (FCS) was not added during in vitro culture, as previously described (Gutiérrez-Ádan et al., 2001). Blastocysts were frozen individually into microtubes containing $10 \mu \mathrm{L}$ of double distilled 
water and stored at $-20^{\circ} \mathrm{C}$, for previous determination of the genetic sex by PCR (polymerase chain reaction) analysis.

In order to obtain embryonic cell DNA for sexing by PCR, each embryo was treated with $5 \mu \mathrm{g}$ of proteinase $\mathrm{K}$ (Invitrogen, Cleveland, USA), for 60 minutes at $37^{\circ} \mathrm{C}$ and for 10 minutes at $98^{\circ} \mathrm{C}$ (for enzyme inactivation).

DNA of each embryo was distributed in two different microtubes (PCR 1 and PCR 2). The PCR 1 primers were: 5'-CCT CCC CTT GTT CAA ACG CCC GGA ATC ATT-3' and 5'-TGC TTG ACT GCA GGG ACC GAG AGG TTT GGG-3' (Bondioli et al., 1989) and the second pair was: 5'-AGG TCG CGA GAT TGG TCG CTA GGT CAT GCA-3' and 5'-AAG ACC TCG AGA GAC CCT CTT CAA CAC GT-3' (Ellis and Harpold, 1986). The PCR 1 detected a sequence of $210 \mathrm{bp}$ specific to the bovine $\mathrm{Y}$ chromosome and the second pair of primers detected an autosomal sequence of $280 \mathrm{bp}$, indicating the presence of bovine genomic DNA. The PCR 2 primers were: 5'-ATC AGT GCA GGG ACC GAG ATG- 3' and 5'-AAG CAG CCG ATA AAC ACT CCT T-3' (Luz et al., 2000). The PCR 2 detected a sequence of 196bp specific to the $\mathrm{Y}$ chromosome.

Amplifications were performed as follows: a) for PCR 1: an initial step at $94^{\circ} \mathrm{C}$ for 10 seconds, 40 denaturation cycles at $94^{\circ} \mathrm{C}$ for 1 minute, annealing at $58^{\circ} \mathrm{C}$ for 1 minute and synthesis at $72^{\circ} \mathrm{C}$ for 1 minute, time extension of 7 minutes at $72^{\circ} \mathrm{C}$ was added at the end of the final cycle; b) for PCR 2 primer: initial step at $94^{\circ} \mathrm{C}$ for 10 seconds, 38 denaturation cycles at $94^{\circ} \mathrm{C}$ for 1 minute, annealing at $58^{\circ} \mathrm{C}$ for 1 minute and synthesis at $72^{\circ} \mathrm{C}$ for 1 minute, time extension of
7 minutes at $72^{\circ} \mathrm{C}$ was added at the end of the final cycle as well.

Three repetitions were performed for each group. Sperm viability and acrosome integrity were analyzed with ANOVA, followed by Tukey's test (SAS, 2002). In order to verify the effect of IVP on sex ratio, a control group was established, instead of considering the theoretical ratio of 50:50. The Chi-square test (SAS, 2002) compared the sex ratio of all treatments with the control group and cleavage and blastocyst rates.

For statistical analysis a difference of $\mathrm{P}<0.05$ was considered significant.

\section{RESULTS AND DISCUSSION}

Increase of sperm viability was observed after all procedures, and the protocols in this study have been used to guarantee sperm viability. After density gradient centrifugation, $4.15 \%$ of the total sperm processed were recovered, with an increase of $20 \%$ in total motility (80\%). Recovery rate after modified swim-up was $18.20 \%$. Alternatively, modified swim-up was associated to the Percoll ${ }^{\mathrm{TM}}$ discontinuous density gradient centrifugation with increase in the method's accuracy rate for X-bearing spermatozoa selection. Currently there are no reports in the literature on this association for bovine sperm sex selection.

The data from the Trypan blue-Giemsa stain comparing the spermatozoa classes (LWI, LWA, DWI and DWA) of modified swim-up, Percoll density gradient, modified swim-up associated to Percoll density gradient and control group are in the Table 1.

Table 1. Membrane and acrosomal integrity means of X-bearing sperm selection procedures

\begin{tabular}{|c|c|c|c|c|}
\hline \multirow[b]{2}{*}{ Procedure } & \multicolumn{4}{|c|}{ Classes of spermatozoa } \\
\hline & LWI & LWA & $\mathrm{DWI}^{1}$ & DWA \\
\hline Control & $9.25 a$ & $52.00 \mathrm{a}$ & $6.38 \mathrm{a}$ & $32.38 \mathrm{a}$ \\
\hline Modified swim-up & $9.75 \mathrm{a}$ & $59.25 \mathrm{ab}$ & $3.25 \mathrm{ab}$ & $23.88 \mathrm{ab}$ \\
\hline Density gradient & $7.00 \mathrm{a}$ & $71.87 \mathrm{bc}$ & $1.65 \mathrm{~b}$ & $20.00 \mathrm{ab}$ \\
\hline $\begin{array}{l}\text { Modified swim-up associated to } \\
\text { density gradient }\end{array}$ & $6.38 \mathrm{a}$ & $79.37 \mathrm{c}$ & $0.63 b$ & $17.88 \mathrm{~b}$ \\
\hline $\operatorname{Pr}>\mathrm{F}$ & $0.2399 \mathrm{~ns}$ & $0.0012 \mathrm{~s}$ & $0.0206 \mathrm{~s}$ & $0.0139 \mathrm{~s}$ \\
\hline
\end{tabular}

Within a column, values without a common letter differ $(\mathrm{P}<0.05)$.

LWI: live with intact acrosome, LWA: live without acrosome, DWI: dead with intact acrosome, DWA: and dead without acrosome

${ }^{\mathbf{1}}$ The DWI variable was transformed to $\sqrt{ } \mathrm{MI}+1$, for ANOVA to be possible. 
Sperm selection procedures induced acrossomal reaction. Modified swim-up associated to density gradient centrifugation selected live spermatozoa but increased acrossomal reaction (79.4\%), when compared with all procedures. Watson (2000) described that thawed spermatozoa procedures cause induced sperm plasmatic membrane damages and induce acrosomal reaction. Nevertheless, in order to develop sex selection procedure using thawed sperm it is important to consider the live spermatozoa with non-reacted acrosome, because the acrosome integrity is a sperm characteristic for fertilization (Parrish et al., 1988). Treatments to separate X-bearing spermatozoa are able to selected viable sperm but promote acrosomal reaction. Therefore, those spermatozoa can be used in IVP systems, and the induction of sperm capacitation with heparin before oocytes insemination is not necessary (Zhang et al., 2003).

No difference in cleavage and blastocyst rates was identified $(\mathrm{P}>0.05)$ among sexing groups (modified swim-up, Percoll $^{\mathrm{TM}}$ density gradient and modified swim-up associated to density gradient) versus control group (Table 2).

Table 2. Means of cleavage and blastocyst rates of in vitro produced bovine embryos with sperm sexed by modified swim-up, density gradient centrifugation and modified swim-up associated to density gradient centrifugation

\begin{tabular}{|c|c|c|c|}
\hline Procedure & Oocyte number & $\begin{array}{l}\text { Cleavage rate } \\
\mathrm{n}(\%)\end{array}$ & $\begin{array}{l}\text { Blastocyst rate } \\
\mathrm{n}(\%)\end{array}$ \\
\hline Control & 2.015 & $1.445(71.71)$ & $522(25.93)$ \\
\hline Modified Swim-up & 255 & $186(72.94)$ & $83(32.55)$ \\
\hline Density gradient centrifugation & 400 & $282(70.50)$ & $110(27.5)$ \\
\hline $\begin{array}{l}\text { Modified swim-up associated to } \\
\text { density gradient centrifugation }\end{array}$ & 363 & $244(67.4)$ & $73(20.17)$ \\
\hline Total of oocytes used & & & 3,033 \\
\hline
\end{tabular}

For in vitro embryo production using sperm selection by PercollTM discontinuous density gradient centrifugation, the cleavage and blastocyst rates $(70.5 \%$ and $27.6 \%$, respectively) were similar to the results obtained by Resende et al., (2010) using Percoll ${ }^{\mathrm{TM}}$ continuous density gradient centrifugation $(70 \%$ and $24 \%$, respectively). Hossepian de Lima et al. (2011) used the same protocol as the present study and observed cleavage and blastocyst rates of $75 \%$ and $30 \%$, respectively.
Modified swim-up is a sperm separation procedure frequently used in bovine and human IVP systems to select viable sperm for oocyte fertilization. Using the methodology described by De Jonge et al. (1997) for embryo production satisfactory cleavage and blastocyst rates $(72.9 \%$ and $32.5 \%$, respectively) were obtained.

Difference in sex ratio was identified $(\mathrm{P}<0.05)$ among sexing groups (modified swim-up, Percoll ${ }^{\text {TM }}$ density gradient and modified swim-up associated to density gradient) versus control group (Table 3).

Table 3. Sex ratio obtained after PCR analysis of in vitro produced bovine embryos with sperm sexed by modified swim-up, density gradient centrifugation and modified swim-up associated to density gradient centrifugation

\begin{tabular}{|c|c|c|c|}
\hline Procedure & Embryo number & $\begin{array}{l}\text { Male } \\
\mathrm{n}(\%)\end{array}$ & $\begin{array}{c}\text { Female } \\
\mathrm{n}(\%)\end{array}$ \\
\hline Control & 427 & $54.80(234)$ & $45.20(193)$ \\
\hline Modified swim-up & 76 & $38.20(29)$ & $61.80(47) *$ \\
\hline Density gradient centrifugation & 89 & $40.60(36)$ & $59.40(53) * *$ \\
\hline $\begin{array}{l}\text { Modified swim-up associated to } \\
\text { density gradient centrifugation }\end{array}$ & 71 & $39.40(28)$ & $60.60(43) * *$ \\
\hline Total of embryos sexed by PCR & & & \\
\hline
\end{tabular}


The sexual deviation in favor of females using thawed semen centrifugation in Percoll ${ }^{\mathrm{TM}}$ discontinuous density gradient was $59.6 \%$ $(\mathrm{P}<0.05)$ in agreement to Resende et al. (2010) using continuous gradient (60\% females). Blottner et al. (1993) demonstrated a deviation of $90 \%$ in favor of females for IVP embryos. In literature results of fresh sperm sexing using Percoll $^{\mathrm{TM}}$ discontinuous density gradient of $55.7 \%$ (Kobayashi et al., 2004) to $74.3 \%$ (Hossepian de Lima, 2007; Hossepian de Lima et $a l ., 2011)$ in favor of females was described.

The deviation towards females could be higher in the present study, whereas control group presented a sex deviation in favor of males $(54.80 \%)$. In vitro maturation longer than 22 hours (Rizos et al., 2008) and the co-incubation oocyte-spermatozoa period (Iwata et al., 2007) induced the deviation in favor of males.

The Y-bearing chromosome is faster than the $\mathrm{X}$ bearing chromosome because $\mathrm{X}$ sperm has more DNA than $\mathrm{Y}$ sperm which results in different migration velocity (Yan et al., 2006). Based on this affirmation, some authors described that supernatant of swim-up procedure contained more Y sperm (Check and Katsoff, 1993; Check et al., 1994). De Jonge et al. (1997), MadridBury et al. (2003), Yan et al. (2006) and Cesari et al. (2006) evaluated the swim-up supernatant and reported no difference between X- and Ybearing sperm proportion. Bottcher-Luiz et al. (1997) observed $69.6 \%$ of X-bearing sperm in supernatant. These results were in agreement with the present study $(61.80 \%$ in favor of females). Rawlings et al. (for review see De Jonge et al., 1997) reported that after swim-up in the supernatant two fractions could be observed: the lower fraction enriched with Y- bearing spermatozoa $(60 \%)$ and the upper enriched with $\mathrm{X}$ - bearing spermatozoa $(64 \%)$.

In bovines X-bearing spermatozoa can be separated by discontinuous density gradient centrifugation, modified swim-up and modified swim-up associated with discontinuous density gradient centrifugation with about $60 \%$ accuracy. The use of X-bearing spermatozoa is possible in IVP of embryo systems with the purpose of reducing the deviation towards males without compromising embryo development.

\section{ACKNOWLEDGMENTS}

The authors acknowledge FAPESP for the funding supplies 05/53174-0 and 05/59357-9.

\section{REFERENCES}

BLOTTNER, S.; SCHWERIN, M.; BÖTTCHER, M.; PITRA, C. Selective enrichment of bovine X-and Y-spermatozoa by Percoll density gradient. Archiv für Tierzucht, v.36, p.153-162, 1993.

BORCHERSEN, S.; PEACOCK, M. Danish AI field data with sexed semen. Theriogenology, v.71, p.59-63, 2009.

BOTTCHER-LUIZ, F.; MAGNA, L.A.; FAZANO, F.A.T. Seleção sexual em dois processos de capacitação espermática: percoll e "swim-up". Reprod. Clim., v.12, p.141-147, 1997.

CESARI, A.G.G.; KAISER, N.; MUCCI, A. et al. Integrated morphophysiological assessment of two methods for sperm selection in bovine embryo production in vitro. Theriogenology, v.66, p.1185-1193, 2006.

CHECK, J.H.; KATSOFF, D. A prospective study to evaluate the efficacy of modified swim-up preparation for male sex selection. Hum. Reprod., v.8, p.211-214, 1993.

CHECK, J.H.; KWIRENK, D.; KATSOFF, D. et al. Male:female sex ratio in births resulting from IVF according to swim-up versus Percoll preparation of inseminated sperm. Arch. Androl., v.33, p.63-65, 1994.

DE JONGE, C.J.; FLAHERTY, S.P.; BARNES, A.M. et al. Failure of mutitube sperm swim-up for sex preselection. Fertil. Steril., v.67, p.1109-1114, 1997.

DE VRIES, A.M.; OVERTON, J.; FETROW, K. et al. Exploring the impact of sexed semen on the structure of the dairy industry. J. Dairy Sci., v.91, p.847-856, 2008.

ELLIS, S.B.; HARPOLD, M.M. (1986): Nucleic acid probes for prenatal sexing. International application published under the Patent Cooperative Treaty (PCT) World Intellectual Property Organization. Publication No. WO 86/07095. 
GUTIÉRREZ-ADÁN， A.; LONERGAN， P.; RIZOS, D. et al. Effect of the in vitro culture system on the kinetics of blastocyst development and sex ratio of bovine embryos. Theriogenology, v.55, p.1117-1126, 2001.

HOSSEPIAN DE LIMA, V.F.M. Aspectos metodológicos na seleção do sexo de espermatozoides bovinos para utilização no melhoramento genético e na produção animal. Rev. Bras. Zootec., v.36, p.219-228, 2007.

HOSSEPIAN DE LIMA, V.F.M.; MOREIRAFILHO, C.A.; LUCIO, A.C.; RESENDE, M.V. Seleção do sexo de espermatozoides bovinos por centrifugação em gradiente descontínuo de densidade de Percoll. Rev. Bras. Zootec., v. 40, p. 1680-1685, 2011.

IRIANNI, F.M.; CODDINGTON, C.C. 3rd. Male factor infertility and assisted reproductive technologies. Current Opinion in Obstetrics \& Gynecology, v.4, p.712-719, 1992.

IWATA, H.; SHIONO, H.; KON, Y. et al. Effects of modification of in vitro fertilization techniques on the sex ratio of the resultant bovine embryos. Anim. Reprod. Sci., v.105, p.234-244, 2008.

JONHSON, L.A. Sexing mammalian sperm for production offspring: the state-of-the-art. Anim. Reprod. Sci., v.60-61, p.93-107, 2000.

KOBAYASHI, J.; OGURO, H.; UCHIDA, H. et al. Assessment of bovine Xand Y-bearing spermatozoa in fractions by discontinuous percoll gradients with rapid fluorescence in situ hybridization. J. Reprod. Dev., v.50, p.463-469, 2004.

KOVACS, A., FOOTE, R.H. Viability and acrosome staining of bull, boar and rabbit spermatozoa. Biotech. Histoch., v.67, p.119-124, 1992.

LUCIO, A.C.; OLIVEIRA, L.Z.; CELEGHINI, E.C.C. et al. Influence of bovine subspecies in the recovered rate after the separation of $\mathrm{X}$ bearing sperm by centrifugation in discontinuous Percoll ${ }^{\mathrm{TM}}$ density gradient. Anim. Reprod. Sci., v.6, p.336, 2008 (Abstarct).

LUZ, M.R.; WATANABE, Y.F.; FERRO, J.A. et al. Sexing o in vitro fertilized bovine embryos by multiplex PCR. Brazilian J. Vet. Res. Anim. Sci., v.37, p.453-456, 2000.
MADRID-BURY, N.; FERNANDEZ, R.; JIMENEZ, A. et al. Effect of ejaculate, Bull, and double swim-up sperm processing method on sperm sex ratio. Zygote, v.11, p.229-235, 2003.

MORTON, K.M.; HERRMANN, D.; SIEG, B. et al. Altered mRNA expression patters in bovine blastocysts after fertilization in vitro using flowcitometrically sex-sorted sperm. Mol. Reprod. Dev., v.74, p.931-940, 2007.

OLIVEIRA, L.Z.; ARRUDA, R.P.; CELEGHINI, E.C.C. et al. Effects of discontinuous Percoll gradient centrifugation on the quality of bovine spermatozoa evaluated with computer-assisted semen analysis and fluorescent probes association. Andrologia, v.44, p.9-15, 2012.

PALMA, G.A.; OLIVIER, N.S.; NEUMÜLER, C.H.; SINOWATZ, F. Effects of sex-sorted spermatozoa on the efficiency of in vitro fertilization and ultrastructure of in vitro produced bovine blastocysts. Anat. Histol. Embryol., v.37, p.67-73, 2008.

PARRISH, J.J.; KROGENAES, A.; SUSKOPARRISH, J.L. Effect of bovine sperm separation by either swim-up or Percoll method on success of in vitro fertilization and early embryonic development. Theriogenology, v.44, p.859-869, 1995.

PARRISH, J.J.; SUSKO-PARRISH, J.L.; FIRST, N.L. Capacitation of bovine sperm by heparin. Biol. Reprod., v.38, p.1171-1180, 1988.

PEREZ-CRESPO, M.; PINTADO, B.; GUTIERREZ-ADAN, A. Scrotal heat stress effects on sperm viability, sperm DNA integrity, and the offspring sex ratio in mice. Mol. Reprod. Dev., v.75, p.40-47, 2008.

PRAKASH, P.; LEYKIN, L.; CHEN, Z. Preparation by differential gradient centrifugation is better than swim-up in selecting sperm with normal morphology (strict criteria). Fertil Steril., v.69, p.722-726, 1998.

RESENDE, M.V.; LUCIO, A.C.; PERINI, A.P. et al. Desvio da proporção de sexo e integridade do DNA dos espermatozoides bovinos centrifugados em gradientes de densidade contínuos. Rev. Bras. Saúde Prod. Anim., v.11, p.260-269, 2010. 
RODRIGUEZ-MARTINEZ, H.; LARSSON, B.; PERTOFT, H. Evaluation of sperm damage and techniques for sperm clean-up. Reprod. Fertil. Dev., v.9, p.297-308, 1997.

RIZOS, D.; BERMEJO-ALVAREZ, P.; GUTIERREZ-ADAN, A.; LONERGAN, P. Effect of duration of oocyte maturation on the kinetics of cleavage, embryo yield and sex ratio in cattle. Reprod. Fertil. Dev., v.20, p.734-740, 2008 .

STATISTICAL Analyses System Institute. SAS. "SAS User's Guide: Statistic". SAS Institute INC., Cary, NC, 2002.

VAJTA, G.; RINDOM, N.; PEURA, T.T. et al. The effect of media, serum and temperature on in vitro survival of bovine blastocysts after open pulled straw (OPS) vitrification. Theriogenology, v.52, p. 939-948, 1999.
WATSON, P. F. The causes of reduced fertility with cryopreserved semen. Anim. Reprod. Sci., v.60-61, p.481, 2000 (Abstract).

WEIGEL, K.A. Exploring the role of sexed semen in dairy production systems. J. Dairy Sci., v.87, Suppl., p.120-130, 2004.

YAN, J.H.L.; FENG, Z.; CHEN, J. et al. Influence of swim-up time on sex ratio of $\mathrm{X}$ - and Y-bearing spermatozoa. European J. Obst. Gynecol. Reprod. Biol., v.129, p.150-154, 2006.

ZHANG, M.; LU, K.H.; SEIDEL, G.E. Development of bovine embryos after in vitro fertilization of oocytes with flow cytrometrically sorted, stained and unsorted sperm from different bulls. Theriogenology, v.60, p.1657-1663, 2003. 